\title{
Similar problems, different solutions: Comparing refuse collection in the Netherlands and Spain
}

\author{
By Germà Bel ${ }^{1}$, Elbert Dijkgraaf ${ }^{2}$, Xavier Fageda $^{3}$ and Raymond Gradus ${ }^{4}$ \\ ${ }^{1}$ PPRE - IREA. Department of Econometrics, University of Barcelona. \\ Avda. Diagonal, 690. 08034 Barcelona, Spain. Email: gbel@ub.edu. \\ ${ }^{2}$ Erasmus University Rotterdam, ECRi. Email: dijkgraaf@few.eur.nl. \\ ${ }^{3}$ PPRE - IREA. Department of Econometrics, University of Barcelona. \\ Avda. Diagonal, 690. 08034 Barcelona, Spain. Email: xfageda@ub.edu. \\ ${ }^{4}$ Vrije Universiteit Amsterdam. Email: rgradus@xs4all.nl.
}

\begin{abstract}
Local public service provision can vary greatly because of differences in institutional arrangements, public service markets, and national traditions regarding government intervention. In this paper we compare the procedures adopted by the local governments of the Netherlands and Spain in arranging for the provision of solid waste collection. We find that Spain faces a consolidation problem, opting more frequently to implement policies of privatization and cooperation, at the expense of competition. By contrast, the Netherlands has, on average, larger municipalities, resorting somewhat less to privatization and cooperation, and more to competition. The two options - cooperation and competition - have their merits when striving to strike a balance between transaction costs and scale economies. The choices made in organizational reform seem to be related to several factors, among which the nature of the political system and the size of municipalities appear to be relevant.
\end{abstract}

Key words: Local governments, contracting-out, privatization, inter-municipal cooperation.

JEL codes: L33, R51, H72.

ACKNOWLEDGEMENTS: Germà Bel and Xavier Fageda thank financial suport from the Spanish Science Commission (SEJ2006-04985). Parts of this paper have been written while Raymond Gradus was visiting Universitat de Barcelona. 


\section{INTRODUCTION}

This paper compares local government systems for the organization of solid waste collection in the Netherlands and Spain, the contracting out of which, it is often argued (e.g., Savas 1987; Domberger and Jensen 1997), serves to improve the efficiency of the service within the public sector. Indeed, contracting out, it has been suggested, may result in a better incentive structure for managers and act to promote competition for the market. Moreover, contracting out would seem to facilitate the exploitation of scale economies (Donahue 1989). However, these potential cost advantages must be set against the higher transaction costs incurred when contracting out. The recent literature has tended to cast doubts on the savings to be made from private production, arguing that asset specificity is also of importance for waste collection, and that the unique characteristics of local service markets means a considerable amount of information is required to guarantee effective competition (Bel, Hebdon and Warner 2007; Dijkgraaf and Gradus 2007; Bel and Warner 2008; Warner and Hefetz 2008). All in all, therefore, governments would appear to play a critical role in managing these markets, where the key question must be whether these authorities have the opportunity to exploit scale economies and promote competition, and -at the same time- to minimize transaction costs.

Spanish municipalities, according to Warner and Bel (2008), are opting increasingly for mixed (public-private) firms and inter-municipal cooperation. In Spain, where little emphasis is placed on competition, the main concern appears to be with maintaining the benefits of economies of scale. However, elsewhere, more specifically in the Netherlands and some of the Scandinavian countries, local authorities implement a more mixed policy, emphasizing certain elements of a competitive market approach while maintaining the benefits of scale economies. Interestingly, in other European countries -such as the UK- inter- 
municipal cooperation is not used for service provision because of the marked emphasis on market methods (Kelly 2007).

Inter-municipal cooperation is also a significant feature in the US, where local fragmentation is marked. In the US, inter-municipal cooperation is usually not compatible with private production (e.g. Warner and Hefetz 2002a, 2002b; Levin and Tadelis 2008), although it is seen as a form of contracting out. Indeed, many US local governments contract out with other local government or public agencies and, as such, delivery is the responsibility of an external (public) producer (Warner and Bel 2008). However, inter-municipal cooperation in the US differs from the way in which this organizational form is understood and implemented in the countries we study here. Neither in the Netherlands nor in Spain does inter-municipal cooperation involve the contracting out to another local government or public agency, rather it involves participating in multi-government joint authorities.

Interestingly, both the Netherlands and Spain are EU members that operate within the latter's framework of legislative competition. However, there is no clear trend towards privatization in these countries (or, for that matter, in Europe as a whole, see Dijkgraaf and Gradus 2008c). In the Netherlands, there has been a comparatively greater emphasis placed on the use of public firms, with considerable managerial autonomy, but with ultimate control remaining in the hands of the owner governments. Today, these public firms compete for contracts with private firms in a growing number of municipalities. By contrast, in Spain less emphasis is given to public firms and where they do exist, they do not compete for contracts outside their own municipality. By way of an alternative, the small average municipality size in Spain has resulted in many instances of inter-municipal cooperation.

Managing the market, either by means of competition or inter-municipal cooperation, is likely to have had positive effects on delivery costs. However, according to empirical evidence for the Netherlands, no systematic cost differences are found when comparing private production with that of public firms that had won a contract through competition 
(Dijkgraaf and Gradus 2003, 2007). Similarly, in the case of Spain, evidence shows that public and private production do not present any systematic cost differences (Bel and Costas 2006), while those municipalities that cooperate report lower costs than those that do not cooperate (with cost differences disappearing in municipalities with more than 20,000 inhabitants, when scale economies have been exploited). Therefore, it is clearly of interest to gain an understanding of the institutional and political structures that can influence choices of solid waste delivery.

This paper provides an explanatory analysis of the nature of differences in solid waste collection in Spain and the Netherlands. In the section that follows, we describe public sector organizations in the two countries, focusing specifically at the local level so as to have a full understanding of the policy environment in which decisions are taken. We then present an overview of the organization of solid waste collection (its collection and transport), but we do not examine the related services of waste treatment, as their nature and competitive environment are markedly different (Dijkgraaf and Gradus 2008c). Next, we analyze both Dutch and Spanish market structures and because of the predominance of private firms, the role of flexible forms is emphasized. This provides a useful framework for the analysis that we undertake in the next section of inter-municipal cooperation in the two countries. Finally, we draw our conclusions.

\section{PUBLIC SECTOR ORGANIZATIONS AND POLITICAL ENVIRONMENT}

Much has been written about the potential influence of ideological factors and political objectives on local privatization decisions. However, the empirical evidence available including literature reviews (Bel and Fageda 2007) and meta-regression analyses (Bel and Fageda 2008b), as well as country-specific evidence for Spain (Bel and Miralles 2003; Bel and Fageda 2008a) and the Netherlands (Dijkgraaf, Gradus and Melemberg 2003) - suggests 
that ideology has not played a particularly relevant role in the privatization of solid waste collection. Political objectives, by contrast, might have had a limited influence on privatization, particularly as regards private interests and their interaction with the local political process. Here we focus on the institutional and political structures in the belief that differences attributable to historical traditions might influence choices in local service delivery.

\subsection{The Netherlands}

In 1996 there were 625 municipalities in the Netherlands (the first and smallest tier of government), but by 2006 , the number of municipalities had fallen to 458 , reflecting in the main the merger of small municipalities. The overall population rose from 15.5 million in 1996 to 16.3 million inhabitants in 2006 , while the average number of inhabitants per municipality in this period increased from 24,790 to almost 35,664 . The largest Dutch city, Amsterdam, today has a population of 739,510 inhabitants. In 2006, 19 municipalities had more than 100,000 inhabitants, while only 64 Dutch municipalities had fewer than 10,000 inhabitants. The second tier of government consists of 12 provinces, with the number of cities in 2006 varying from just six (Flevoland) to 83 (Zuid-Holland). Elections usually take place every four years, and are proportional and based on a party list.

The mayor and aldermen form the municipality's executive board. The former is appointed by central government, and his or her executive powers are limited. The number of aldermen varies according to the number of inhabitants. Since 2002, aldermen do not have to be members of the municipal council, although they need the support of the majority of the council. In general, the parties represented on the executive board form a majority in the council. The same structure applies also to the provinces. The Royal Commissioner and deputies form the executive board. The former is appointed by central government, and his or her executive powers are also limited. In the Netherlands, the role of the provinces in the 
provision of government services is somewhat limited. Nevertheless, the provinces do play an important role in implementing environmental law.

\subsection{Spain}

Local government has several jurisdictions. The first, and most basic, is the municipality. Unlike the Netherlands, Spain has not experienced a consolidation of these entities, so while in 1996 there were 8,097 municipalities by 2006 this figure had increased to 8,110. Many of these are particularly small: in $1996,5,931$ municipalities ( $73 \%$ of the total) had fewer than 2,000 inhabitants, while in 2006 , the number had fallen slightly to $5,836(72 \%$ of the total). Hence, the average population per municipality is low: the average number of inhabitants per municipality was 4,899 in 1996 and 5,513 in 2006. This increase in the average size reflects, in the main, the marked increase in the population of Spain due to immigration between 2001 and 2006 (8.8\%).

Local elections in Spain are based on party lists and the members of the municipal council are elected on a proportional basis. The mayor is then elected indirectly by the municipal council members. An absolute majority is required for a mayor to be elected after the first round of voting. If no candidate obtains this majority then the name leading the list that obtained most votes at the local election is elected mayor. The mayor is responsible for appointing the members of the municipal government, all of whom must be members of the municipal council.

The next tiers in the local government framework are constituted by the counties ('comarcas') and provinces (hereinafter 'provincias' to distinguish them from the Dutch provinces). The counties are to be found in just a few regions (e.g., Catalonia), whereas the provincias exist all over Spain, totaling 50 in all. In general, the county and provincial governments ('Diputación') are elected indirectly. Their respective councils are formed on the basis of the results obtained in the local elections by all the parties that participated in the 
territory of each jurisdiction. Only members of the municipal councils can sit as members of the county council and the provincial council too. The members of the county/provincial council elect the president, and he/she is responsible for appointing the members of the corresponding government, all of whom must be members of the council.

\subsection{Summary}

At the municipal level the differences between Spain and the Netherlands are particularly great. The average Spanish municipality is smaller in population than its Dutch counterpart. Interestingly, the central government appoints the Dutch mayor, while the municipal council elects the Spanish mayor and, as a result, the Spanish municipal executive power is more politically oriented. The same characteristics are equally apparent at the provincial level. Table 1 summarizes the main differences between the two countries.

\section{[Insert Table 1]}

Local governments in Spain enjoy greater power when it comes to engaging more flexible organizational forms such as mixed public-private firms. They have greater freedom to set up joint political governance bodies, which in turn enjoy greater flexibility when deciding how to organize the delivery of the solid waste collection service, e.g., by municipal cooperation. These differences are particularly significant in the case of the service that concerns us here, solid waste collection. Empirical evidence indicates that scale economies exist in this service for populations around 20,000 inhabitants (Stevens, 1978; Dijkgraaf and Gradus, 2003, Bel and Costas, 2006). Therefore, as most Spanish municipalities fall below this optimal size, strong local power means that more flexible organizational forms (such as cooperation) in order to address this scale problem can be experimented with.

\section{ORGANIZATION OF SOLID WASTE COLLECTION}

Dutch and Spanish municipalities are under a legal obligation to provide collection services for municipal waste, but they are free to choose whether to deliver this service 
themselves or to contract it out to outside firms. In this section we describe the organization of the solid waste collection market in both countries.

\subsection{Data and sources}

Our data on the amount of waste and the methods of waste treatment applied in the Netherlands are for 2006 and are based on a dataset for all 458 municipalities produced by the Dutch Waste Management Council (see Senternovem, 2006). Data for Spain are for 2003 and are taken from the II Survey on Local Services, conducted in 2003-2004 by the research unit 'Public policies and economic regulation' (ppre), at the University of Barcelona. This survey provides information for 540 municipalities with a population above 2,000 inhabitants, which represents almost $25 \%$ of Spanish municipalities of this size. It is worth remembering at this point that the average population of the Spanish municipalities with more than 2,000 inhabitants is 18,402 . This figure is considerably greater than the overall Spanish average $(5,513)$, and much closer to the average Dutch population $(35,664)$. Hence, while differences in population sizes are initially important, restricting the Spanish sample to cities above 2,000 reduces such differences in average size and allows more meaningful comparisons to be made. Bel (2006) contains detailed information on the survey methodology and the data.

\subsection{The Netherlands}

In 2006, 174 Dutch municipalities (38\% of the total, representing $29 \%$ of the population) were contracting out waste collection to a private firm, while 115 municipalities ( $25 \%$ of the total, representing $27 \%$ of the population) were contracting the service out to a public firm. Over the last decade, public firms have begun to compete with private firms for contracts (Dijkgraaaf and Gradus 2008b). Today, therefore, contracting out involves both private and public firms, and is a practice adopted in $63 \%$ of the municipalities (representing $58 \%$ of the population). A third group, $14 \%$ of the municipalities ( $9 \%$ of the population) operate a municipal waste collection service in cooperation with neighboring cities. The 
remaining municipalities collect the waste themselves (i.e., $23 \%$ of the municipalities, representing $35 \%$ of the population). Tables $2 \mathrm{a}$ and $2 \mathrm{~b}$ show detailed information of these practices.

[Insert Table 2a and Table 2b]

Unlike in Spain, a public body is responsible for overseeing compulsory intermunicipal cooperation in the Netherlands. Below, we discuss this issue in more detail. Mixed firms do not exist in the Netherlands. Over time the number of municipalities using a public firm has increased, while municipal cooperation and self-supply has decreased, and private collection has remained more or less stable (Dijkgraaf and Gradus 2008a). Interestingly, in large Dutch cities self-supply is much more common than firm delivery, while in small municipalities firms play a much larger role.

\subsection{Spain}

In the case of Spain, we only have data for municipalities with more than 2,000 inhabitants. In 2003, $56 \%$ of these municipalities contracted out solid waste collection to private firms and, thus, two-thirds of the population were served by a private firm, since the average population of municipalities with private production is higher than that of municipalities with public production. Direct production (bureaucracy) was present in almost a quarter of the municipalities (15\% of the population), whereas $12 \%$ of the municipalities (and $12 \%$ of the population) were served by a public firm, which ultimately comes under government control but which, nevertheless, operates under private law. Tables $3 \mathrm{a}$ and $3 \mathrm{~b}$ show more detailed information.

(Insert Table 3a and Table 3b)

Finally, $7 \%$ of the municipalities ( $6 \%$ of the population) in 2003 were served by mixed firms. As Warner and Bel (2008) explain ownership in these mixed firms is shared between the government and the private sector, with the government retaining an important stake in 
the firm, albeit that the firm's operations are governed by private commercial law. The private partner tends to be a large firm with a consolidated position in the market for the private production of the local service. In such instances, the day-to-day business is usually conducted by the private industrial partner, with the government retaining control over certain strategic decisions. Within this organizational framework, municipal (or supra-municipal) governments enter into long-term contracts with private firms through joint venture agreements.

Little can be said about the dynamics of the waste collection sector in Spain, since upto-date data are unavailable for the country as a whole. However, data for the region of Catalonia show that practices involving contracting out to private contractors are stable over time. In $2000,81.7 \%$ of Catalan municipalities with a population over 1,000 inhabitants had resorted to private production for their waste collection (Bel and Costas 2006). In 2006 the use of private firms stood at 81.2\% (Bel and Fageda 2007b).

\subsection{Summary}

A comparison of practices in Spain and the Netherlands shows that market shares for direct production by the municipality (bureaucracy) are quite similar in the two countries if measured in terms of the number of municipalities (though this is not the case if measured in terms of the share of population). Private firms have a higher share of the market in Spain, while the market share of public firms is much higher in Netherlands than it is in Spain.

In Spain, private production is virtually equivalent to contracting out, since public firms only collect waste within their own municipalities. One reason for this can be local governments in Spain have more power than their Dutch counterparts. Hence, political competition between cities might well be stronger, and this might have led to a certain reluctance on the part of some authorities to contract out to another government, and thus discouraged competition from public firms. Finally, local public firms in Spain require legal 
authorization before they can participate in contracts outside their jurisdiction, and the bureaucratic procedures that must be gone through in order to obtain this permission can be lengthy and taxing. These obstacles serve to discourage public firms from competing for external contracts. Thus, in Spain there tends to be no competition for contracts between public and private firms, whereas in the Netherlands levels of competition are on the increase.

Interestingly, in the Netherlands public production increases with municipality size, while in Spain public production is more common among the smaller municipalities. Bel and Miralles (2003) suggest that this pattern reflects the fact that the high transaction costs associated with the contracting out of the service have a greater impact on the smallest municipalities. However, the trade-off between the savings to be made from contracting out and the high transaction costs is enhanced if the population increases.

Finally, inter-municipal cooperation is not strictly comparable between the two countries. In the Netherlands, inter-municipal cooperation typically involves a few municipalities whose joint efforts to deliver this service, and all other municipal co-operation agreements for that matter, are run as a public service. By contrast, in Spain inter-municipal cooperation tends to mean that municipal governments engage in partnerships under a joint authority in governance in which all the governments play a role. In this situation, a choice can then be made between different forms of service delivery: public production, private production, or mixed firms. Hence, inter-municipal cooperation is not strictly linked to public production, and cooperation and privatization are not incompatible (Bel and Fageda, 2006 2008a). Below we discuss inter-municipal cooperation in more detail.

\section{MARKET STRUCTURE}

Here we describe the structure of the solid waste collection market using a measure of concentration, the Hirschman-Herfindahl index (HHI). HHI can be defined as the sum of the 
squared market shares, and lies between 0 (full competition) and 1 (monopoly). The number of (artificial) competitors active in the market can be estimated by $1 / \mathrm{HHI}$. The advantage of using HHI over simple concentration rates consists in its ability to take into account the number of firms and the differences between them (spread in size). To provide additional information, the concentration ratios $\mathrm{CR} 1$ and $\mathrm{CR} 4$ were also considered. CR1 is defined by the market share of the largest company, while CR4 is the market share of the four largest companies.

\subsection{The Netherlands}

Three firms dominate the market in the Netherlands: SITA serves 74 municipalities, Van Gansewinkel 32, and AVR 23. The activity of SITA is evenly spread over the country (being active in 10 of the 12 provinces). Van Gansewinkel is active in six provinces (above all in the south of the country). Interestingly, AVR began life as a public company in the region of Rijnmond, becoming private in 2006, and today it is active in four provinces. These large private firms are active in small and large municipalities alike. This characteristic is also clear if we divide the markets into municipality size groups. As can be seen in Tables $4 a$ and $4 b$, SITA is the leading firm in all groups, both in terms of concessions and population. The market shares of Van Gansewinkel and AVR are also surprisingly stable over the different groups, although they exchange second and third places with each other. The Tables clearly illustrate the dominance of these three firms on the private side of the market. However, their market position would seem to have been weakened by the entry of a number of public firms. Indeed, in those provinces in which public firms have entered the market for contracts, prices have fallen (Dijkgraaf and Gradus 2008b).

[Insert Table 4a and Table 4b]

The 2006 Herfindahl concentration index for private firms in the Dutch national market is 0.23 with respect to population and 0.24 with respect to the number of 
municipalities (or concessions). Compared with a threshold value of 0.18 used by the regulators, this means that the market is concentrated. If we take the province as our level of study, the concentration is even higher, although it is not spread evenly over the country. Some provinces do not have any private collection firms at all (Flevoland and Friesland), while others have a high incidence of such firms. At this provincial level, the HHI stands between 0.22 (Noord-Brabant) and 1.0 (Drenthe).

As discussed above, public firms are increasingly acting as competitors for private firms and, as such, the HHI can be calculated by including these public firms as well. At the national scale, the 2006 Herfindahl index is now only 0.08 (see Table 5) suggesting a competitive market. Still, concentration might be intense at the provincial level, since the Herfindahl index is very high for a number of provinces. At this provincial level, the HHI stands between 0.16 (Noord-Brabant) and 1.0 (Friesland), with all contracts being awarded to just one public firm.

\section{[Insert Table 5]}

The increasing importance of Dutch public firms becomes apparent also if we compare the HHI over time. In Table 5 the two HHIs are compared for the years 2002 and 2006. The HHI has decreased overtime, both when public firms are excluded and included. However, for the private $\mathrm{HHI}$ the decrease is more moderate than for the HHI including public firms. Interestingly, in some provinces municipal co-operation has resulted in the creation of public firms, thus strengthening competition further.

\subsection{Spain}

In Spain, the market share of the leading firm (Fomento de Construcciones y Contratas FCC) reaches $33 \%$ of concessions and $52 \%$ of the population served (Bel, 2006). The two other leading firms are Ferrovial-Cespa (18\% of concessions and $17 \%$ of the population) and ACS-Urbaser (14\% of concessions, $16 \%$ of the population). Taken together, all three major firms concentrate $65 \%$ of the concessions and $85 \%$ of the population served. If we consider 
the market of the larger municipalities separately (population $>10,000$ ), the share of the leading firms is even higher ( $72 \%$ of concessions together). If we add together the market shares of the first four leading groups, we see that they concentrate two-thirds of the concessions (three-quarters in medium and large size cities) and almost $90 \%$ of the population. As discussed earlier, public firms do not compete for concessions in Spain, so here we only consider private firms in our analysis of market concentration. Tables $6 \mathrm{a}$ and $6 \mathrm{~b}$ display detailed information.

[Insert Table 6a and Table 6b]

The Herfindahl-Hirschman index is 0.16 for concessions and 0.33 for population. Compared with the threshold value of 0.18 , the market is indeed concentrated. Moreover, the results at the regional level usually show degrees of concentration that are higher than those found for Spain as a whole.

Since the data available for the Spanish market relates to just one year, we cannot draw any inferences about the dynamics of concentration over time. However, comparable data for the region of Catalonia in 2000 and 2006 show a trend of increasing concentration in this region, as Table 7 shows. Our data for Catalonia are taken for 2000 and 2006 and are based on a survey of local services run by the ppre research unit at the University of Barcelona and the Catalan Competition Commission [detailed information regarding survey methodology and data can be consulted in Bel and Costas (2006) and Bel and Fageda (2007b)]. Indeed, the HHI for concessions increased by almost $25 \%$ between 2000 and 2006, while the HHI for population served increased by $13 \%$ between these two dates. As the incidence of contracting out to private firms did not change in this period, the concentration of the largest firms has in all likelihood increased. Since Catalonia is the region with the largest private market of concessions, our evidence suggests that increasing concentration should be a concern for the whole country. 


\section{[Insert Table 7]}

Spain has a dual market, which in the case of the Netherlands is not so marked. Market concentration indexes for the Spanish market provide strong evidence for the existence of this dual market (Bel 2008, Bel and Fageda 2008c). Major firms are more likely to be the contract holders in large municipalities as well as in those municipalities in which more firms have participated in the bid for the last contract. Hence, major firms tend to operate in large municipalities (as well as at the supra-national level even, with some of them being active players in foreign markets, including the United Kingdom, Davies 2007). Although more firms participate in the bids for the most profitable contracts, the three major firms are the usual bidders. Given that the average number of bidders is below four, even in the largest municipalities, there would seem to be a highly oligopolistic sector in this segment of the market. By contrast, smaller regional or local firms are more likely to be the contract holders in small municipalities, which similarly tend not to receive many bids for their contracts. Thus, these smaller firms can operate as a local monopoly that does not suffer any market competition, because very few firms (if any, other than the incumbent,) tend to participate in the bids for the contract (Bel and Fageda 2008c).

\subsection{Summary}

Concentration indexes in the Netherlands are lower than those in Spain, and show a tendency to decrease rather than increase. In the Netherlands, the difference between concentration indexes when public firms are alternately excluded and included is relevant, as public firms in this country bid for contracts in municipalities outside their own jurisdiction, which is not the case in Spain. The expanding role of Dutch public firms probably counteracts the natural tendency of private firms, as can be seen in Spain.

In Spain, the dominance of the major firms in the large municipalities combined with local monopolies in small municipalities seems to indicate that the intensity of competition in 
local markets is lower than optimal from a social welfare point of view. It also tells an interesting story in terms of market dominance and political power. According to findings reported in Bel and Fageda (2008c) in their study of the region of Catalonia, large nationwide firms tend to be associated with contracts awarded by municipalities that are governed by national political parties, whereas municipalities ruled by regional parties seem more likely to award contracts to local or micro-regional private firms. This would appear to suggest quite clearly that market dominance has important political implications for local governments. In the Netherlands as well, the dominance of the private parties is important, but the political links are much weaker than in Spain.

\section{IMPORTANCE OF INTER-MUNICIPAL COOPERATION}

\subsection{Netherlands}

In the Netherlands, inter-municipal cooperation (WGR) is employed for certain government services including fire brigades, solid waste collection and health care. Municipalities are free to choose whether they actually work together in the WGR or they prefer to operate alone. For solid waste collection, only $14 \%$ of the Dutch municipalities use inter-municipal cooperation, falling from 19\% in 2002 (Dijkgraaf and Gradus 2008b). The organizations that manage inter-municipal cooperation (hereinafter 'cooperations') are not only responsible for waste collection, but actually collect the waste themselves. They act, therefore, as a substitute for a municipal public unit or a firm (public or private).

There are no direct elections for WGR board members and inter-municipal cooperations are mainly run by the mayors and some aldermen. On a day-to-day basis, civil servants manage the municipal cooperations, and, as such, the political profile of the municipal cooperation is low. All cooperations are run as a public service. Some of the political parties are, however, in favor of direct elections for municipal cooperations.

\subsection{Spain}


In Spain, almost half the municipalities with a population above 2,000 provide solid waste collection through inter-municipal cooperation. Table 8 shows the frequency of intermunicipal cooperation in Spain and the different forms of production (private, public and mixed) used under inter-municipal cooperation. It should be noted that through intermunicipal cooperation, municipal governments engage in partnerships under a joint authority (either a supramunicipal institution -at the county or province level-, or a single purpose agency), the governance of which is assumed by all the governments involved. Within this framework, the choice is made between private production, public production or mixed firms for service delivery. Thus, cooperation and privatization are not incompatible in Spain (Bel and Fageda 2006, 2008). Indeed, the county or the provincial council decides what form of production is to be used to deliver solid waste collection. It is worth noting that municipalities are free to retain municipal provision or to engage in inter-municipal cooperation, as this remains a municipal responsibility.

\section{[Insert Table 8]}

Cooperation tends to be more frequent among small municipalities, indicating that it is used as a method to take advantage of scale economies. In addition, inter-municipal cooperation is more frequent in municipalities that retain public production, suggesting that it may be used as an alternative to privatization as well. On the relationship between cooperation and delivery costs, the evidence is mixed. In Spain, inter-municipal cooperation is linked significantly to lower costs (Bel and Costas 2006, Mur 2008). By contrast, in the Netherlands cooperation is associated with higher costs (Dijkgraaf and Gradus 2007). Internationally, this issue has not been analyzed in many countries. However, a cost disadvantage for cooperation has also been reported in Norway (Sørensen 2008, 1055). It seems that the type of cooperation prevalent in Spain is unique, since it fully exploits scale economies with low transaction costs.

\subsection{Summary}


In Spain the use of inter-municipal cooperation is three times greater than in the Netherlands. Moreover, Spanish inter-municipal cooperation is compatible with privatization, while in the Netherlands it is not. There would appear to be two main explanations for these differences. First, the average Spanish municipality size is small and, hence, there is a greater need for cooperation. Second, public firms and mergers between municipalities would seem to constitute an alternative to exploit scale economies in the Netherlands.

The literature on cooperative competition and the 'Third Italy' strategy has emphasized the advantage of geographically concentrated networks of enterprises (e.g., Hansen, 1992) and their successful adoption by efficient local governments in Italy has been reported as significant (Brusco, 1982). Nonetheless, this does not appear to be the case with the inter-municipal cooperation described here, since no network of local firms or units has developed. In fact, a single organization (public in the Netherlands; public, private or mixed in Spain) is in charge of waste collection. One likely rationale for engaging in cooperation is the ability to exploit economies of scale while preserving public monopoly as a form of service delivery. In Spain, moreover, inter-municipal cooperation may result from the attempts made by small governments to enter the market for private contracts when they take the decision to contract out, since half the municipalities that cooperate have that service contracted out.

\section{DISCUSSION}

Table 9 summarizes the main differences identified in this paper in solid waste collection in Spain and the Netherlands.

\section{[Insert Table 9]}

While private production is much more frequent in Spain than it is in the Netherlands, the frequency of contracting out is relatively similar in both countries. The explanation for this would seem to lie in the differences in the services of public firms. In Spain, public firms 
generally deliver the service only in the municipality(ies) that owns that particular firm. By contrast, in the Netherlands, it is quite common for public firms to bid for contracts in other municipalities. Since public firms in Spain do not usually operate beyond the limits of their own jurisdiction, contracting out is in practice equivalent to private market practices.

The fact that public firms do not operate outside the boundaries of their jurisdiction means that other public firms from outside a specific jurisdiction do not usually constitute an alternative when private contracts fail. It is perhaps because of this that mixed public-private firms (partial privatization) are relatively common in Spain, whereas they do not exist in the Netherlands. The political power wielded by local governments is stronger in Spain than it is in the Netherlands; because of this, their municipalities can engage in complex organizational forms (which include sharing firm ownership with the private sector). In this sense, greater levels of discretional power in Spain are linked to greater organizational flexibility.

Whereas the use of hybrid organizational forms, such as mixed public-private firms, can solve problems of contract failure and lack of capabilities or competence for public delivery in Spain, it is not a viable alternative in order to maintain a competitive environment in the solid waste collection market. Concentration indexes in the Netherlands are smaller than those in Spain, and while in the Netherlands concentration is decreasing, in Spain it would seem to be increasing. This can be explained by the fact that public firms in the Netherlands bid for contracts in municipalities outside their own jurisdiction, which is not the case in Spain. In the Netherlands, involving public firms in tendering seems to serve to increase competition and to reduce the market power of private contractors. In Spain, public firms, mixed firms and private firms do not interact with each other. Hence, public competitors bring no competitive pressure to bear on private contractors.

A further institutional difference with significant ramifications for market structure is the fact that Spain has many more municipalities and that their average population is much smaller than in the Netherlands. One consequence of this is the existence in Spain of a dual 
market for solid waste, with large municipalities and large firms operating in one half, and small cities and towns with local and regional firms operating in the other. It is not profitable for large firms to operate in small cities and towns, while small local and regional firms do not have the capability to operate in large cities and metropolitan areas. As these two markets are no more than only slightly connected, competition is damaged. By contrast, large firms in the Netherlands operate across municipalities of all sizes. Indeed, population density and municipality size (inhabitants) in the Netherlands is greater, which means that most contracts have a potential appeal for the major players.

The restrictions imposed on Spanish municipalities due to low population levels (a small private market with a small number of suppliers), together with the considerable political power that local governments wield have led many small cities and towns to engage in intermunicipal cooperation whereby the compatibility of this type of provision with all production forms is preserved. Through inter-municipal cooperation small Spanish municipalities can exploit scale economies without the need to contract a private firm or, alternatively, they can achieve greater joint bargaining power in order to initiate a contracting process. By contrast, incidences of inter-municipal cooperation in the Netherlands are much less frequent. As, unlike in Spain, inter-municipal cooperation has a cost disadvantage in the Netherlands, a finding in line with reports in Sørensen (2008).

In short, Spain has a consolidation problem, typified by more instances of privatization and cooperation, but lower levels of competition. The Netherlands, on the other hand, presents a greater average municipality size, and as a result we find fewer instances of privatization, and less cooperation. Public firms are more widely used in the Netherlands, and this helps to some degree to overcome the competition problem resulting from the increasing levels of concentration that are emerging in the private market. The differences between the two countries as regards the size of their municipalities, the power wielded by local 
governments, and the extent to which public firms operate are key factors in accounting for these differences.

Overall, contracting out might lead to saving costs thanks to the exploitation of scale economies and the promotion of market competition (Bel, Hebdon and Warner 2007). However, contracting out might also lead to higher transaction costs. Spain and the Netherlands adopt distinct organizational forms in order to deal with both scale economies and transaction costs. Spanish local governments quite frequently resort to inter-municipal cooperation and mixed firms, while the use of public firms and the merging of municipalities is frequent in the Netherlands. One lesson that the Netherlands might learn could well be that a more powerful political framework for municipal cooperation is desirable if it wishes to implement more flexible organizational forms.

Market competition may be weak in both countries as the concentration is relatively high. However, in the Netherlands the increasing importance of public firms as external players in concessions for delivering waste has improved market competition. As regards concentration, therefore, the Dutch solution would seem to provide better results. And it is here that a lesson of potential interest emerges for Spain: encouraging public firms to compete for contracts outside their own particular municipality could enhance competition and restrict positions of dominance. 


\section{References}

AOO. 2002. Afvalstoffenheffingen 2002 (Waste taxes 2002), Utrecht.

Bel, G. 2006. Economía y política de la privatización local. Madrid: Marcial Pons.

Bel, G. 2008. 'Refuse collection service in Spain: privatisation, inter-municipal cooperation, and market concentration', in E. Dijkgraaf and R.H.J.M. Gradus (eds.), The Waste Market: Institutional Developments in Europe, Springer Science,83-100.

Bel, G. and A. Costas. 2006. 'Do public sector reforms get rusty? Local privatization in Spain', Journal of Policy Reform, 9, 1, 1-24.

Bel, G. and X. Fageda. 2006. 'Between privatization and inter-municipal cooperation: Small municipalities, scale economies and transaction costs', Urban Public Economics Review, 0, 6, 13-31.

Bel, Germà, and X. Fageda. 2007a. 'Why do local governments privatize public services? A survey of empirical studies', Local Government Studies, 33, 4, 517-534.

Bel G. and X. Fageda. 2007b. La privatització de serveis locals: concentració empresarial $i$ competència a catalunya. Barcelona: Universitat de Barcelona and Tribunal Català de Defensa de la Competència.

Bel, G. and X. Fageda. 2008a. Reforming the local public sector: Economics and politics in privatization of water and solid waste', Journal of Economic Policy Reform, 11, 1, 45 65.

Bel, G. and X. Fageda. 2008b. 'Factors explaining local privatization: a meta-regression analysis", Public Choice, forthcoming.

Bel, G. and X. Fageda. 2008c. Privatization and competition in the delivery of local services: An empirical examination of the dual market hypothesis. Universitat de Barcelona: working paper.

Bel, G., R. Hebdon, and M. Warner. 2007. 'Local government reform: Privatisation and its alternatives', Local Government Studies, 33, 4, 507-515.

Bel, G. and A. Miralles. 2003. 'Factors influencing privatization of urban solid waste collection in Spain', Urban Studies, 40, 7, 1323-1334.

Bel, G. and M.E. Warner. 2008. 'Does privatization of solid waste and water services reduce costs? A review of empirical studies', Resources, Conservation \& Recycling, 52, 12 , $1337-1348$.

Brusco, S. 1982. 'The Emilian model: productive decentralisation and social integration', Cambridge Journal of Economics, 6, 2, 167-184. 
Davies, S. 2007. Politics and Markets: The Case of UK Municipal Waste Management. Paper presented at the 2007 APPAM Fall Conference, Washington DC, USA.

Dijkgraaf, E., and R.H.J.M. Gradus. 2003. 'Cost savings of contracting out refuse collection'. Empirica, 30, 2, 149-61.

Dijkgraaf, E., R.H.J.M. Gradus and B. Melenberg. 2003. 'Contracting out refuse collection', Empirical Economics, 28 3, 553-570.

Dijkgraaf, E. and R.H.J.M. Gradus. 2007. 'Collusion in the Dutch waste collection market', Local Government Studies, 33, 4, 573-588.

Dijkgraaf, E. and R.H.J.M. Gradus. 2008a. 'Institutional Developments in the Dutch Waste Market', Environment and Planning C: Government and Policy, 26, 1, 110-126.

Dijkgraaf, E. and R.H.J.M. Gradus. 2008b. 'How to get increasing competition in the Dutch refuse collection market', in E. Dijkgraaf and R.H.J.M. Gradus (eds.), The Waste Market: Institutional Developments in Europe, Springer Science, 101-109.

Dijkgraaf, E. and R.H.J.M. Gradus. 2008c. 'Introduction', in E. Dijkgraaf and R.H.J.M. Gradus (eds.), The Waste Market: Institutional Developments in Europe, Springer Science, 1-9.

Domberger, S. and P. Jensen. 1997. 'Contracting out by the public sector: theory, evidence, prospects', Oxford Review of Economic Policy, 13, 4, 67-78.

Donahue, J.D. 1989. The privatization decision. Public ends, private means. New York, NY: Basic Books.

Hansen, N. 1992. 'Competition, trust, and reciprocity in the development of innovative regional milieu', Papers in Regional Science, 71, 2, 95-105.

Hefetz, A. and M.E. Warner. 2004. 'Privatization and Its Reverse: Explaining the Dynamics of the Government Contracting Process', Journal of Public Administration Research and Theory, 14, 2, 171-90.

Kelly, J. 2007. 'The curious absence of inter-municipal cooperation in England', Public Policy and Administration, 22, 3, 319-334.

Levin, J. and S. Tadelis. 2008. 'Contracting for government services: Theory and evidence from U.S. cities', Journal of Industrial Economics, forthcoming.

Mur, M. 2008. Factores que influyen en los costes de producción del servicio de RSU: Una estimación para el caso aragonés. Universidad de Zaragoza, Ph Dissertation, chapter 4.

Savas, E. 1987. Privatization: The key to better government. Chatham, NJ: Chatham House Publishers.

Senternovem. 2006. Afvalstoffenheffingen 2006 (Waste taxes 2006), Utrecht. 
Sørensen, R.J. 2007. 'Does Dispersed Public Ownership Impair Efficiency? The Case of Refuse Collection in Norway', Public Administration, 85, 4, 1045-1058.

Stevens, B.J. 1978. 'Scale, market structure, and the cost of refuse collection', Review of Economics and Statistics, 60, 3, 438-48.

Warner, M.E. and G. Bel. 2008. 'Competition or monopoly? Comparing privatization of local public services in the US and Spain', Public Administration, 86, 3, 723-735.

Warner, M.E. and A. Hefetz. 2002a. 'Applying market solutions to public services: An assessment of efficiency, equity and voice', Urban Affairs Review, 38, 1, 70-89.

Warner, M.E. and A. Hefetz. 2002b. 'The uneven distribution of market solutions for public goods', Journal of Urban Affairs, 24, 4, 445-459.

Warner, M.E. and A. Hefetz. 2008. 'Managing Markets for Public Service: The Role of Mixed Public/Private Delivery of City Services', Public Administration Review, 68, 1, 155-166. 


\section{Tables}

Table 1: Main differences in public sector organization

\begin{tabular}{|c|c|c|}
\hline & Netherlands & Spain \\
\hline Number of municipalities (2006) & 458 & 8,110 \\
\hline Average size (2006) & 35,664 & $5,513 \quad(18,402)^{*}$ \\
\hline Mayor & $\begin{array}{l}\text { Appointed by Central } \\
\text { Government }\end{array}$ & $\begin{array}{l}\text { Elected (indirectly) in } \\
\text { local election }\end{array}$ \\
\hline Empowerment of local government & Limited & Strong \\
\hline
\end{tabular}

Table 2a: Form of production of refuse collection in Netherlands. Municipalities

\begin{tabular}{|l|l|l|l|l|l|}
\hline \multicolumn{5}{|l|}{ Netherlands (2006) } \\
\hline Municipality size (population) & $\begin{array}{l}\text { Public Unit } \\
\text { (Bureaucracy) }\end{array}$ & $\begin{array}{l}\text { Public } \\
\text { Firm }\end{array}$ & $\begin{array}{l}\text { Mixed } \\
\text { Firm }\end{array}$ & $\begin{array}{l}\text { Private } \\
\text { Firm }\end{array}$ & Other \\
\hline $986-10,000$ & $9.4 \%$ & $25.0 \%$ & $0.0 \%$ & $40.6 \%$ & $25.0 \%$ \\
\hline $10,001-30,000$ & $19.5 \%$ & $23.6 \%$ & $0.0 \%$ & $44.3 \%$ & $12.6 \%$ \\
\hline $30,001-50,000$ & $27.7 \%$ & $20.5 \%$ & $0.0 \%$ & $37.3 \%$ & $14.5 \%$ \\
\hline $50,001-100,000$ & $42.5 \%$ & $32.5 \%$ & $0.0 \%$ & $12.5 \%$ & $12.5 \%$ \\
\hline More than 100,000 & $44.0 \%$ & $44.0 \%$ & $0.0 \%$ & $12.0 \%$ & $0.0 \%$ \\
\hline Total (weighted) & $22.9 \%$ & $25.1 \%$ & $0.0 \%$ & $38.0 \%$ & $14.0 \%$ \\
\hline
\end{tabular}

Table 2b: Form of production of refuse collection in Netherlands. Population

\begin{tabular}{|l|l|l|l|l|l|}
\hline & \multicolumn{3}{l|}{ Netherlands (2006) } \\
\hline Municipality size (population) & $\begin{array}{l}\text { Public Unit } \\
\text { (Bureaucracy) }\end{array}$ & $\begin{array}{l}\text { Public } \\
\text { Firm }\end{array}$ & $\begin{array}{l}\text { Mixed } \\
\text { Firm }\end{array}$ & $\begin{array}{l}\text { Private } \\
\text { Firm }\end{array}$ & Other \\
\hline $986-10,000$ & $10.3 \%$ & $26.8 \%$ & $0.0 \%$ & $40.9 \%$ & $21.9 \%$ \\
\hline $10,001-30,000$ & $23.1 \%$ & $23.1 \%$ & $0.0 \%$ & $41.9 \%$ & $11.9 \%$ \\
\hline $30,001-50,000$ & $34.3 \%$ & $20.6 \%$ & $0.0 \%$ & $30.5 \%$ & $14.6 \%$ \\
\hline $50,001-100,000$ & $34.4 \%$ & $47.8 \%$ & $0.0 \%$ & $12.0 \%$ & $5.8 \%$ \\
\hline More than 100,000 & $67.0 \%$ & $7.5 \%$ & $0.0 \%$ & $25.6 \%$ & $0.0 \%$ \\
\hline Total (weighted) & $35.3 \%$ & $26.6 \%$ & $0.0 \%$ & $28.7 \%$ & $9.4 \%$ \\
\hline
\end{tabular}

Source: Senternovem (2006) and authors' own calculations 
Table 3a: Form of production of refuse collection in Spain. Municipalities

\begin{tabular}{|l|l|l|l|l|l|}
\hline & \multicolumn{5}{l|}{ Spain (2003) } \\
\hline Municipality size (population) & $\begin{array}{l}\text { Public Unit } \\
\text { (Bureaucracy) }\end{array}$ & $\begin{array}{l}\text { Public } \\
\text { Firm }\end{array}$ & $\begin{array}{l}\text { Mixed } \\
\text { Firm }\end{array}$ & Private Firm & Other \\
\hline $2,001-10,000$ & $27.1 \%$ & $13.0 \%$ & $8.2 \%$ & $51.7 \%$ & $0.0 \%$ \\
\hline $10,001-30,000$ & $20.0 \%$ & $9.2 \%$ & $4.3 \%$ & $66.5 \%$ & $0.0 \%$ \\
\hline $30,001-50,000$ & $14.5 \%$ & $18.4 \%$ & $2.6 \%$ & $64.5 \%$ & $0.0 \%$ \\
\hline $50,001-100,000$ & $9.6 \%$ & $11.0 \%$ & $5.5 \%$ & $72.6 \%$ & $1.4 \%$ \\
\hline More than 100,000 & $14.0 \%$ & $17.5 \%$ & $3.5 \%$ & $64.9 \%$ & $0.0 \%$ \\
\hline Total (weighted) & $24.2 \%$ & $12.4 \%$ & $7.0 \%$ & $56.3 \%$ & $0.1 \%$ \\
\hline
\end{tabular}

Table 3b: Form of production of refuse collection in Spain. Population

\begin{tabular}{|l|l|l|l|l|l|}
\hline & Spain (2003) & Other \\
\hline Municipality size (population) & $\begin{array}{l}\text { Public Unit } \\
\text { (Bureaucracy) }\end{array}$ & $\begin{array}{l}\text { Public } \\
\text { Firm }\end{array}$ & $\begin{array}{l}\text { Mixed } \\
\text { Firm }\end{array}$ & $\begin{array}{l}\text { Private } \\
\text { Firm }\end{array}$ & \\
\hline $2,001-10,000$ & $26.1 \%$ & $10.8 \%$ & $8.8 \%$ & $54.3 \%$ & $0.0 \%$ \\
\hline $10,001-30,000$ & $19.6 \%$ & $9.5 \%$ & $4.5 \%$ & $66.4 \%$ & $0.0 \%$ \\
\hline $30,001-50,000$ & $15.1 \%$ & $18.9 \%$ & $2.6 \%$ & $63.4 \%$ & $0.0 \%$ \\
\hline $50,001-100,000$ & $9.5 \%$ & $10.8 \%$ & $5.0 \%$ & $73.0 \%$ & $1.7 \%$ \\
\hline More than 100,000 & $9.5 \%$ & $14.1 \%$ & $5.3 \%$ & $71.1 \%$ & $0.0 \%$ \\
\hline Total (weighted) & $14.8 \%$ & $12.4 \%$ & $5.6 \%$ & $67.0 \%$ & $0.2 \%$ \\
\hline
\end{tabular}

Notes: In building the figure for 'Total', gross percentages resulting from the sample have been adjusted. To do so, we have taken into account the different frequency of responses to the Survey obtained across municipality sizes.

Other means that the city territory is divided in different service areas. One (or some) of them are served by public firms and one (or some) are served by private firms.

Municipalities over 2,000 pop. $\mathrm{n}=540$

Source: Based on Bel, G. 2006. Economía y política de la privatización local (Economics and Politics of Local Privatization). Madrid: Marcial Pons, 196 \& 198.

Table 4a. Market shares (in \%) and concentration indexes in Netherlands. Concessions private firms 2006

\begin{tabular}{|ll|l|l|l|l|l|l|l|l|l|}
\hline & $\mathrm{N}$ & $\begin{array}{l}\text { Leading } \\
\text { Group }\end{array}$ & Share & $\begin{array}{l}\text { Second } \\
\text { Group }\end{array}$ & Share & $\begin{array}{l}\text { Third } \\
\text { Group }\end{array}$ & Share & CR1 & CR4 & HHI \\
\hline Total & 174 & SITA & $42.0 \%$ & Gansew. & $20.1 \%$ & AVR & $13.2 \%$ & 0.420 & 0.828 & 0.241 \\
\hline Total (pop $>10,000)$ & 148 & SITA & $41.9 \%$ & Gansew. & $22.3 \%$ & AVR & $12.2 \%$ & 0.419 & 0.838 & 0.247 \\
\hline Munic. Pop $>30,000$ & 39 & SITA & $35.9 \%$ & Gansew. & $28.2 \%$ & AVR & $15.4 \%$ & 0.359 & 0.821 & 0.238 \\
\hline Pop. 10,001 to 30,000 & 109 & SITA & $44.0 \%$ & Gansew. & $20.2 \%$ & AVR & $11.0 \%$ & 0.440 & 0.844 & 0.256 \\
\hline Munic. Pop $<10,000$ & 26 & SITA & $42.3 \%$ & AVR & $19.2 \%$ & Gansew. & $7.7 \%$ & 0.423 & 0.769 & 0.235 \\
\hline
\end{tabular}

Table 4b. Market shares (in \%) and concentration indexes in Netherlands. Population served by private firms 2006.

\begin{tabular}{|ll|l|l|l|l|l|l|l|l|l|}
\hline & $\mathrm{N}$ & $\begin{array}{l}\text { Leading } \\
\text { Group }\end{array}$ & Share & $\begin{array}{l}\text { Second } \\
\text { Group }\end{array}$ & Share & $\begin{array}{l}\text { Third } \\
\text { Group }\end{array}$ & Share & CR1 & CR4 & HHI \\
\hline Total & 174 & SITA & $35.6 \%$ & Gansew. & $23.8 \%$ & AVR & $20.5 \%$ & 0.356 & 0.853 & 0.231 \\
\hline Total (pop $>10,000)$ & 148 & SITA & $35.3 \%$ & Gansew. & $24.4 \%$ & AVR & $20.6 \%$ & 0.353 & 0.857 & 0.232 \\
\hline Munic. Pop $>30,000$ & 39 & SITA & $29.1 \%$ & AVR & $28.6 \%$ & Gansew. & $28.3 \%$ & 0.291 & 0.875 & 0.249 \\
\hline Pop. 10,001 to 30,000 & 109 & SITA & $43.1 \%$ & Gansew. & $19.6 \%$ & AVR & $10.7 \%$ & 0.431 & 0.833 & 0.248 \\
\hline Munic. Pop $<10,000$ & 26 & SITA & $41.8 \%$ & AVR & $19.0 \%$ & Gansew. & $8.9 \%$ & 0.418 & 0.771 & 0.239 \\
\hline
\end{tabular}

Source: Senternovem (2006) and authors' own calculations

Table 5: Change overtime in the concentration index (HHI) in the Netherlands

\begin{tabular}{|l|l|l|}
\hline Data year & HHI private & HHI private/public \\
\hline 2002 & 0.27 & 0.11 \\
\hline 2006 & 0.23 & 0.08 \\
\hline
\end{tabular}

Note: the HHI is calculated in population.

Source: AOO (2002) and Senternovem (2006) and authors' own calculations 
Table 6a. Market shares (in \%) and concentration indexes in Spain. Concessions 2003

\begin{tabular}{|ll|ll|ll|ll|llll|}
\hline & N & $\begin{array}{l}\text { Leading } \\
\text { Group }\end{array}$ & Share & $\begin{array}{l}\text { Second } \\
\text { Group }\end{array}$ & Share & $\begin{array}{l}\text { Third } \\
\text { Group }\end{array}$ & Share & CR1 & CR4 & HHI \\
\hline Total & 350 & FCC & $32.9 \%$ & Ferrovial & $18.3 \%$ & Urbaser & $14.0 \%$ & 0.329 & 0.680 & 0.163 \\
\hline Total (pop > 10,000) & 282 & FCC & $36.2 \%$ & Ferrovial & $19.1 \%$ & Urbaser & $16.7 \%$ & 0.362 & 0.745 & 0.198 \\
\hline Munic. Pop > 30,000 & 144 & FCC & $39.9 \%$ & Ferrovial & $22.9 \%$ & Urbaser & $19.6 \%$ & 0.396 & 0.840 & 0.251 \\
\hline Pop. 10,001 to 30,000 & 138 & FCC & $32.6 \%$ & Ferrovial & $15.1 \%$ & Urbaser & $13.0 \%$ & 0.326 & 0.638 & 0.152 \\
\hline Munic. Pop $<10,000$ & 68 & FCC & $19.1 \%$ & Ferrovial & $14.7 \%$ & $*$ & $*$ & 0.191 & 0.412 & 0.071 \\
\hline
\end{tabular}

Table 6b. Market shares (in \%) and concentration indexes in Spain. Population served by private firms 2003.

\begin{tabular}{|ll|ll|ll|ll|lll|}
\hline & N & $\begin{array}{l}\text { Leading } \\
\text { Group }\end{array}$ & Share & $\begin{array}{l}\text { Second } \\
\text { Group }\end{array}$ & Share & $\begin{array}{l}\text { Third } \\
\text { Group }\end{array}$ & Share & CR1 & CR4 & HHI \\
\hline Total & 350 & FCC & $52.0 \%$ & Ferrovial & $16.9 \%$ & Urbaser & $16.2 \%$ & 0.520 & 0.862 & 0.326 \\
\hline Munic. Pop $>30,000$ & 144 & FCC & $55.2 \%$ & Ferrovial & $17.1 \%$ & Urbaser & $16.1 \%$ & 0.552 & 0.906 & 0.361 \\
\hline Pop. 10,001 to 30,000 & 138 & FCC & $33.4 \%$ & Urbaser & $16.2 \%$ & Ferrovial & $14.7 \%$ & 0.334 & 0.677 & 0.164 \\
\hline Munic. Pop $<10,000$ & 68 & Ferrovial & $19.7 \%$ & FCC & $17.7 \%$ & $*$ & $*$ & 0.197 & 0.464 & 0.084 \\
\hline
\end{tabular}

Note: * The sample of municipalities with a population below 10,000 does not allow us to identify with sufficient accuracy the name of the third group/firm in this segment.

Source: Based on Bel, G. 2006. Economía y política de la privatización local (Economics and Politics of Local Privatization). Madrid: Marcial Pons, P. 243.

Table 7: Change overtime in the concentration index (HHI) in Catalonia

\begin{tabular}{|l|l|l|l|}
\hline & Data year & HHI concessions & HHI population \\
\hline Sample 1 (103) & 2000 & 0.106 & 0.268 \\
\hline Sample 2 (103) & 2006 & 0.131 & 0.304 \\
\hline
\end{tabular}

Note: In brackets, number of municipalities in the sample. Original sources are the survey used in Bel and Costas (2006) for 2000 and a more recent survey conducted on behalf of the Antitrust Commission of Catalonia for 2006 (Bel and Fageda 2007b). Both surveys provided information on a larger sample of municipalities with private production: 152 for 2000 and 207 for 2006. To compare concentration indexes in both years we have selected all municipalities (103) for which information was obtained in both surveys.

Hence, the sub-samples used are strictly comparable.

Source: Analysis of Surveys on Local Services conducted in 2000 and 2006/2007.

Table 8. Intermunicipal cooperation in solid waste collection in Spain, 2003, municipalities $>$ 2,000 inhabitants

\begin{tabular}{|l|l|l|}
\hline & Municipalities & Mean population \\
\hline Cooperation at supramunicipal level & $44.0 \%$ & 20,128 \\
\hline Production form (only municipalities that cooperate) & & \\
Private production & $51.3 \%$ & 23,330 \\
Public production & $38.6 \%$ & 17,219 \\
Mixed firm production & $10.1 \%$ & 15,003 \\
\hline
\end{tabular}

Source: Based on Bel, G. 2006. Economía y politica de la privatización local (Economics and Politics of Local Privatization). Madrid: Marcial Pons, P. 223 \& 226. 
Table 9: Overview of differences between the Netherlands and Spain.

\begin{tabular}{|l|l|l|}
\hline & Netherlands & Spain \\
\hline Inter-municipal cooperation compatible with & Public production & All forms of production \\
\hline Mixed firms & No & Yes \\
\hline Dual Market & No & Yes \\
\hline Private production $^{\text {a }}$ & $26 \%$ & $67 \%(73 \%)$ \\
\hline Tendering $^{b}$ & $58 \%$ & $67 \%$ \\
\hline Division $^{c}$ & No & Yes \\
\hline
\end{tabular}

${ }^{\text {a }}$ In number of inhabitants in 2006 in the Netherlands, and in 2003 in Spain. In Spain also mixed firms are included in the percentage in brackets.

${ }^{\mathrm{b}}$ In number of inhabitants in 2006. In the Netherlands public firms are also included.

${ }^{\mathrm{c}}$ In Spain a few large municipalities have been divided in districts for delivery. The main examples are Barcelona (4) and Valencia (2).

Source: Authors' own. 